\title{
Research on the Geological Disaster Forecast and Early Warning Model Based on the Optimal Combination Weighing Law and Extension Method: a Case Study in China
}

\author{
Yichen Zhang ${ }^{1,2}$, Feng Zhang ${ }^{1 *}$, Jiquan Zhang ${ }^{1 * *}$, Enliang Guo ${ }^{1}$, \\ Xingpeng Liu ${ }^{1}$, Zhijun Tong ${ }^{1}$ \\ ${ }^{1}$ Nature Disaster Research Institute, School of Environment, Northeast Normal University, \\ Changchun 130117, People's Republic of China \\ ${ }^{2}$ Jilin Institute of Geological Environmental Monitoring, \\ Changchun 130021, People's Republic of China
}

Received: 20 December 2016

Accepted: 22 February 2017

\begin{abstract}
Geological disaster causes loss of lives and damage to man-made and natural stuctures. In this paper, a coupling method with optimal combination weighing law and extension model was established. Based on dynamic impact factors such as forest coverage, annual average rainfall, topography and gemorphogy, geologic structure, and type of rock and soil, the amount of disaster points and human engineering activities, we chose Jilin Province in China as the case study area. We made a spatial analysis and drew a geological disaster susceptibility zonation map using GIS technology. In addition, we established a geological disaster forecast and early-warning model. The results are as follows: 1) the couple method is an innovative and significant exploration, 2) geological disaster susceptibility zones in Jilin Province were divided into four areas, and 3) the forecasting and early warning model has a relatively high accuracy of forecast and early warning.
\end{abstract}

Keywords: geological disaster, forecast and early warning model, optimal combination of empowerment theory, extension model

\section{Introduction}

Geological disaster causes damage to natural and social environments. The reasons that geological disasters occur

*e-mail: zhangf093@nenu.edu.cn

**e-mail: zhangjq022@nenu.edu.cn are complex and from the slow change to the mutation process under the joint action of a combination of natural and artificial factors [1]. The concept of geological disaster is dealt with by many scholars respectively. The most acceptable definition is that under the influence of atmosphere, hydrosphere, and biosphere, a series of geological process or geological phenomenon occur on the surface of earth's lithosphere such as collapse, landslide, 
debris flow, ground collapse, ground fissure, and ground subsidence, etc. by natural or artificial interference, which damage human lives, property, and the environment.

China is one of the most serious geological disasters in the world. Every year there are a large number of geological disasters. Each of the past nearly 20 years has seen a major geological disaster that causes the death of more than 100 people in China. Especially in recent years, under the impact of such factors as extreme weather, earthquakes, and engineering construction, geological disaster occurrence has become prone and frequent, causing serious damage to people's lives and property. According to incomplete statistics by the Chinese Institution of Geological Environmental Monitoring, abrupt geological disasters such as collapses, landslides, and debris flows caused 10,499 deaths or disappearances, 65,356 injuries, and 57.5 billion CNY of property loss during 1995-2003. The average annual deaths and disappearances were 1,167 and property losses were 6.4 billion CNY. To prevent and reduce geological disasters scientifically and efficiently and reduce the casualties and economic losses caused by geological disasters, the State Council of China issued a national document named The Decision of the State Council on Strengthening Prevention and Control of Geological Disasters (2011) No. 20, which clearly states strengthening the monitoring, forecasting, and early warning of geological disasters.

The Jilin provincial geological environment is quite complex, especially in the southeast mountain area, where geological disasters occur frequently every year. The main types include collapse, landslide, debris flow, and ground collapse. Geological disasters cause an average 10 million CNY economic losses a year. In 2010, under the influence of extreme weather, geological disasters in the flood season number is the sum of the past 30 years. These geological disasters have caused 9 deaths and 790 million CNY in economic losses. The geological disasters have caused serious threats to lives and property security and affected national economic development.

With the continuous expansion of the scope and scale of activities of human engineering, the occurrence frequency of the geological disaster will likely have increasing trends, and the harm to society will also increase [2-4]. A lot of research indicates that most geological disasters are caused or directly triggered by rainfall, so according to the rainfall data for geological disasters, forecasting and early warning are feasible [5]. Through the construction of geological hazard forecasting and warning systems, it is a great help to enhance the research level of coupling the meteorological factors and geological environment mechanisms. With the threshold rainfall criteria quantified, the accuracy of forecasting and warning is improving, which is helpful for territorial management and planning and construction of major projects and security operations services [6]. Geological disaster forecast and early warning is also able to improve citizens' awareness of disaster prevention and mitigation, enhance the pertinence and validity of mass monitoring and preventing geological disasters, and promote the geological disaster prevention and control work of local governments at all levels to reduce the loss of life and property in the flood season.

Geological disasters are born of natural events that cause loss of lives and damage to man-made and natural structures [7-8]. Geological disaster susceptibility zonation is an important step in geological disaster investigation and risk management [9]. There has been significant growth in the investigation of both the early warning models and early warning zonation mapping. Various methods have been proposed by many different scholars [10-17]. These methods fall into three broad categories: statistical, soft computing, and analytical. The statistical methods have been widely used over the last decade. This kind of approch includes information value ( $\mathrm{InV}$ ), logistic regression (LR), the analytical hierarchy process, frequency ratio, and so on [18-29]. The soft computing method is the implementation of the methods mentioned above in geographical information systems (GIS) [3038]. GIS technology has been used widely everywhere and every study area in the world. There is no exception in calculating and managing geological disasters [39-41]. Based on the visible GIS platform, zonation mapping is a relatively easy task.

Usually, the literature mentioned above applies the Inv method, LR model, and some other methods seqarately in geological disaster susceptibility studies [42-43]. This paper applies an optimal combination of empowerment method and the extenics model to the same study area, and a spatial analysis is made by GIS technology. Based on the zonation results, with the antecedent precipitation data, a geological disaster forecast and early-warning model of Jilin province is established. This paper takes Jilin Province, China as a case study.

\section{Materials and Methods}

\section{Study Area}

Jilin Province is located in the central part of northeastern China, with an area of $187,400 \mathrm{~km}^{2}$, accounting for about $2 \%$ of the country's land area (see Fig. 1). The geographical coordinates range from $121^{\circ} 38^{\prime} \mathrm{E}-131^{\circ} 19^{\prime} \mathrm{E}$ and $40^{\circ} 52^{\prime} \mathrm{N}-46^{\circ} 18^{\prime} \mathrm{N}$. The general terrain trend of Jilin is high in the southeast and low in the northwest. The study area is divided into two regions by the northeastern to southwestern Dahei Mountain Range - the Changbai Mountain area and the Western Songliao Plain - belonging to the new Department of Huaxia uplift and subsidence, respectively, accounting for $60 \%$ and $40 \%$ area of the whole province, respectively. The peak elevation of 2,691 $\mathrm{m}$ in Changbai Mountain is the highest point in the province, and is also the highest peak of northeastern China. Songliao plain elevation is below $120 \mathrm{~m}$, while the lowest point is $4 \mathrm{~m}$. The relative altitude difference of the surface structure of the province is more than $2,600 \mathrm{~m}$. Geological disasters in Jilin province are characterized as wide distribution, of various kinds and serious threats. Major geological disasters include collapse, landslide, 


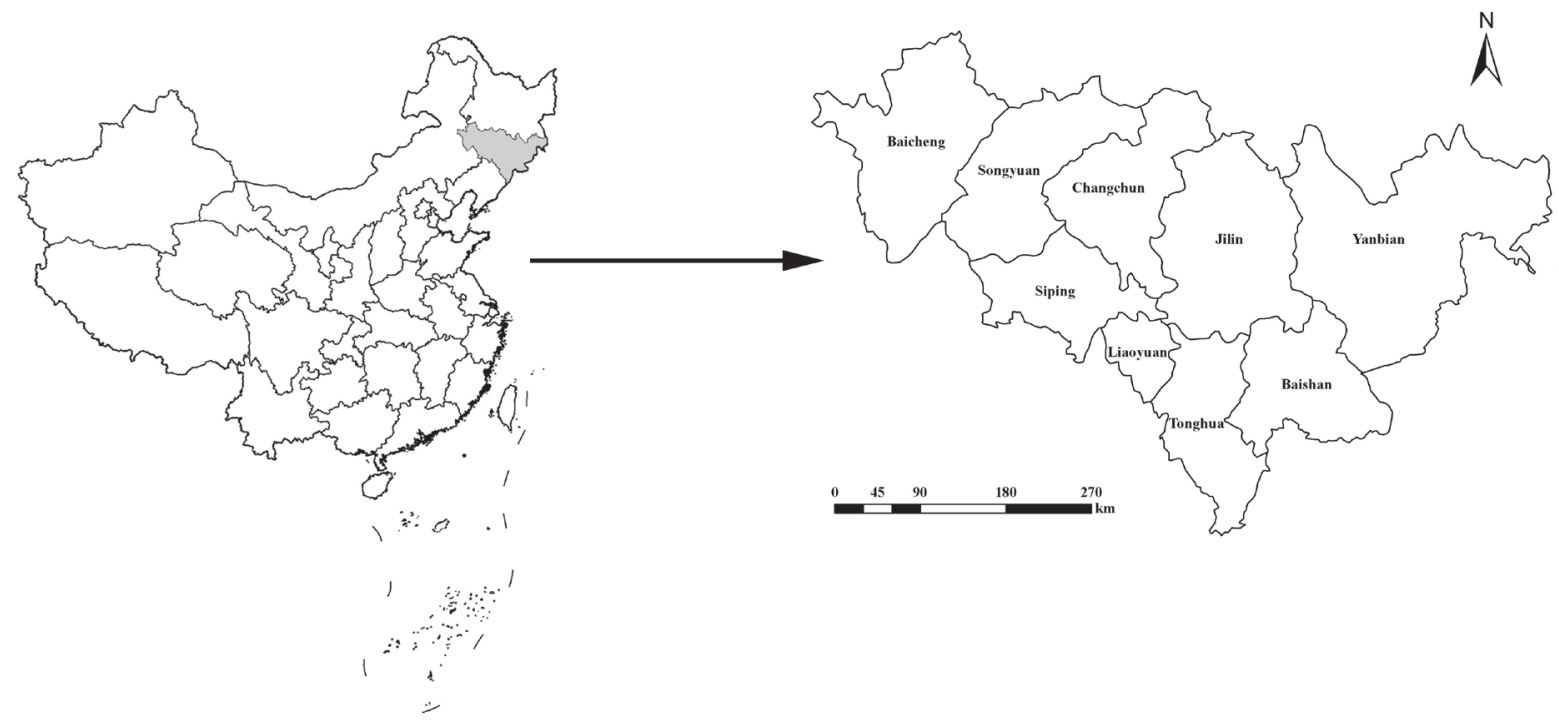

Fig. 1. Location of study area.

debris flow, ground collapse, and ground fissure. After geological disaster investigation and regionalization of results and statistics of 38 counties (cities or districts) in mountain and hill areas, there are currently a total of 3,915 geological disasters in the province.

\section{Optimal Combination of Empowerment Theory}

The main purpose of optimization theory is to find the optimal solution in many programs. The optimal combination of empowerment theory is considered with $m$ objects and $n$ attributes, and under the conditions of the group decision model, which contains L decision-making participants, coordinating several single-model weights and selecting the preferred one [44]. In this paper, the weight-determined preference ratio method and entropy method were chosen to optimize the combination, and dealt with an optimization problem instead of weight problems. Finally, weight determination met the subjective judgment and objective analysis of combinatorial optimization.

\section{Preference Ratio Method}

Preference ratio method is a subjective judgment based on the evaluators to evaluate the importance of indicators [45]. It is based on pairwise comparison of all participating indicators to determine the indicators of the evaluation results of the actual contribution rate. Different from the traditional scale of the AHP method, the evaluation of the preference ratio has been re-defined (Table 1). To a certain extent, the method both reflects the will of the experts and also with the actual situation.

The number of known evaluation is $n$ and the indexes $C=\left\{c_{1}, c_{2}, \ldots c_{n}\right\}$. In order to facilitate the model, it may be assumed in order of importance among the various indicators as $\left.c_{1} \geq c_{2} \geq \ldots c_{n}\right\} \cdot a_{i j}(i, j=1,2, \ldots n)$, which are defined as the ratio scale values of $c i$ and $c j$. The following Eq.(1) can be created:

$$
\left\{\begin{array}{c}
a_{11} p_{1}+a_{12} p_{2}+\cdots+a_{1 n} p_{n}=n p_{1} \\
a_{22} p_{2}+a_{23} p_{3}+\cdots+a_{2 n} p_{n}=(n-1) p_{2} \\
\cdots \\
a_{n-1, n-1} p_{n-1}+a_{n-1, n} p_{n}=2 p_{n-1} \\
p_{1}+p_{2}+\cdots p_{n}=1
\end{array}\right.
$$

$\ldots$ where $\left.0 \leq p_{\mathrm{j}} \leq 1, j=1,2, \ldots n\right), p_{\mathrm{j}}$ is the wanted weight.

\section{Entropy Method}

Entropy was named by the founder of information theory in Mathematical Theory of Communication in 1948. It is commonly known as information entropy. In information systems, information entropy is a measure of the information on the degree of disorder. The greater its value, the higher the degree of disorders of the information and the smaller the utility value of the information. Conversely, the smaller the information entropy, the smaller the degree of disorders of the information and the

Table 1. Ratio scale between factors.

\begin{tabular}{|c|c|}
\hline $\begin{array}{c}\text { The relative preference of } \\
\text { indicators } C_{i} \text { and } C_{j}\end{array}$ & Ratio scale value \\
\hline$C_{i}$ is very much stronger & 5.0 \\
\hline$C_{i}$ is much stronger & 4.0 \\
\hline$C_{i}$ is stronger & 3.0 \\
\hline$C_{i}$ is slightly stronger & 2.0 \\
\hline$C_{i}$ and $C_{j}$ are similar & 1.0 \\
\hline Comparison of $C_{i}$ and $C_{j}$ & Reciprocal of the ratio \\
\hline Middle level of the two & Average value of the ratio scale \\
\hline
\end{tabular}


greater the value of the usefulness of the information, and the more it contributes to evaluation results. The entropy method is used [46-48], and the data information is used to determine the weight coefficient as follows:

With $m$ objects and $n$ evaluations, each index attributes value of bij (bij rep- resents $i$ index of the $j$ object attribute values), and information entropy is a dimensionless quantity. Therefore, before calculating, the weight of each index of the data is normalized. The standardized decision matrix is $B=\left\{b_{i j}\right\}_{m \times n}$ Command:

$$
k_{i j}=\frac{b_{i j}}{\sum_{i=1}^{m} b_{i j}}, i=1,2, \ldots m ; j=1,2, \ldots n
$$

... and the information entropy is:

$$
h_{j}=-(\ln \mathrm{n})^{-1} \sum_{i=1}^{m} k_{i j} \ln k_{i j}, j=1,2, \ldots n
$$

Information entropy can be used to measure the information utility value of the index. In a completely disordered system, the degree of orderliness is zero, and its entropy value is $\max . h j=1$; the utility value of information evaluation of $h j$ is 0 . Therefore, the information utility value of an indicator depends on the difference between the information entropy index $h j$ and 1. So the $j$ th indicator weight is:

$$
q_{j}=\frac{1-h_{j}}{\sum_{j=1}^{n}\left(1-h_{j}\right)}, j=1,2, \ldots n
$$

\section{Optimal Combination Weighting Model}

As mentioned above, this model considers with $m$ objects and $n$ attributes and assumes that the coefficient of optimal combination weight is as below:

$$
W=\left(\omega_{1}, \omega_{2}, \cdots, \omega_{n}\right)^{T}
$$

...where

$$
\omega_{j}=x_{1} p_{j}+x_{2} q_{j}(j=1,2, \cdots, n)
$$

...where $p_{j}$ and $q_{j}$ are the weights of preference ratio method and entropy method, respectively. $x_{1}, x_{2}$ are combined weight-vector linear coefficient. If we assume:

$$
\left\{\begin{array}{l}
x_{1}, x_{2} \geq 0 \\
x_{1}^{2}+x_{2}^{2}=1
\end{array}\right.
$$

...then the key point of this method is converted to determining the value of $x_{1}$ and $x_{2}$. According to the basic linear weighting method, the multi-indicators comprehensive assessment value of $i$-th object is calculated by vector $w_{j}$. The formula is as below:

$$
D_{i}=\sum_{j=1}^{n} b_{i j} \omega_{j}, i=1,2, \cdots, m
$$

Because the more decentralized the $D_{i}$ value, the better the $w_{j}$ value, and the optimal combination of empowerment model can convert into an optimizing equation set as below:

$$
\left\{\begin{array}{l}
\max F\left(x_{1}, x_{2}\right)=\sum_{i=1}^{m} D_{i}^{2}=\sum_{i=1}^{m}\left(\sum_{j=1}^{n}\left(x_{1} p_{j}+x_{2} q_{j}\right) b_{i j}\right)^{2} \\
x_{1}, x_{2} \geq 0 \\
x_{1}^{2}+x_{2}^{2}=1
\end{array}\right.
$$

As the traditional weighting vectors are generally not meeting the normalization constraints, the optimal coefficients are obtained by the normalization of $x^{\prime}$, and $x_{2}^{\prime}$

$$
x_{1}^{\prime \prime}=\frac{x_{1}^{\prime}}{x_{1}^{\prime}+x_{2}^{\prime}}, x_{2}^{\prime \prime}=\frac{x_{2}^{\prime}}{x_{1}^{\prime}+x_{2}^{\prime}}
$$

Then the optimal combination of empowerment model is:

$$
W=x_{1}^{\prime \prime} p_{j}+x_{2}^{\prime \prime} q_{j}
$$

\section{Extenics Theory}

The extenics theory was first put forward by a Chinese scholar named Cai Wen in 1983 [49]. And then many other scholars have improved the theory and applied it to solving contradictory problems [50-51]. The theory can describe that an object's dependent degree values are acquired from $(-\infty,+\infty)$, which reflects both the mutual transform between "yes" and "no." Because the objective world is full of uncertain matters, the dependent degree reflecting whether it belongs to a certain degree makes the evaluation results more precise and more profound [5253].

Using the extenics thory to evaluate the objective problem, the basic idea is to classify the assessment target based on data values firstly and then build an extension model. Bringing the index into the sets of each levels to take a multi-index assessment, according to the associated degree between the evaluation result and the set of the each levels, the levels of the objects were determined. 
The extenics defined an ordered ternary which combines matter, chracteristics of the matter, and value as the fundamental element in this theory and is called a matter-element. This definition can be described as follows Eq.(12):

$$
R=\left[\begin{array}{ccc}
N, & C_{1,} & V_{1} \\
& C_{2}, & V_{2} \\
\vdots & \vdots \\
& C_{n,} & V_{n}
\end{array}\right]
$$

...where R represents a $n$-dimensions matter-element, $N$ denotes the degree of a certain matter, $C_{i}$ represents the characteristics of the matter, and $V_{i}$ represents the value of the characteristic for the matter. The main pocess includes five steps as follows:

\section{Determine the Classical Domain and Domain}

$R_{j}\left(N_{j}, C, V_{j}\right)=\left[\begin{array}{ccc}N_{j}, & C_{1}, & V_{1 j} \\ & C_{2}, & V_{2 j} \\ \vdots & \vdots \\ & C_{n}, & V_{n j}\end{array}\right]=\left[\begin{array}{ccc}N_{j}, & C_{1}, & \left(a_{1 j}, b_{1 j}\right) \\ & C_{2}, & \left(a_{2 j}, b_{2 j}\right) \\ & \vdots & \vdots \\ & C_{n}, & \left(a_{n j}, b_{n j}\right)\end{array}\right]$

...where $N_{j}$ represents the $j$-th degree $(j=1,2, \ldots, m)$; $C_{i}(i=1,2, \ldots, n)$ represents the characteristics of $N_{j}$; and $V_{i j}=\left(a_{i j}, b_{i j}\right)$ represents the value range of $C_{i}$, named classical domain.

$R_{p}\left(P, C, V_{p}\right)=\left[\begin{array}{ccc}P, & C_{1}, & V_{1 p} \\ & C_{2}, & V_{2 p} \\ \vdots & \vdots \\ & C_{n}, & V_{n p}\end{array}\right]=\left[\begin{array}{ccc}P, & C_{1}, & \left(a_{1 p}, b_{1 p}\right) \\ & C_{2}, & \left(a_{2 p}, b_{2 p}\right) \\ \vdots & \vdots \\ & C_{n}, & \left(a_{n p}, b_{n p}\right)\end{array}\right]$

...where $P$ represents a matter-element, $V_{i p}$ represents the value range of $C_{i}$, named domain.

\section{Determining the Assessment Matter-Element}

For the assessing object $P$, to present data and results by matter-element, the assessment matter-element is determined.

$$
R_{j}(P, C, v)=\left[\begin{array}{ccc}
P, & C_{1}, & v_{1} \\
& C_{2}, & v_{2} \\
\vdots & \vdots \\
& C_{n}, & v_{n}
\end{array}\right]
$$

...where $P$ is the object to evaluate, $C_{i}$ represents the factors impacting the degree, and $v_{i}$ represents the value of $C_{i}$, which is the data from the object to evaluate.

\section{Determining the Weight Coefficient}

Weight coefficient is an important degree of quantitative evaluation standard. Different weights get different results. Therefore, it plays a decisive role in determining the accuracy of the results. The optimal combination of empowerment method combinated preference ratio method and entropy method is used to determine the weight coefficient of each evaluation index.

\section{Determining the Relevancy Degree}

The relevancy degree of single indicator $v_{i}$ on degree $j$ is calculated as follows:

$K_{j}\left(v_{i}\right)= \begin{cases}\frac{\rho\left(v_{i}, V_{i j}\right)}{\rho\left(v_{i}, V_{i p}\right)-\rho\left(v_{i}, V_{i j}\right)}, & \rho\left(v_{i}, V_{i p}\right)-\rho\left(v_{i}, V_{i j}\right) \neq 0 \\ -\rho\left(v_{i}, V_{i j}\right), & \rho\left(v_{i}, V_{i p}\right)-\rho\left(v_{i}, V_{i j}\right)=0\end{cases}$

...where

$$
\begin{aligned}
& \rho\left(v_{i}, V_{i j}\right)=\left|v_{i}-\frac{a_{i j}+b_{i j}}{2}\right|-\frac{a_{i j}-b_{i j}}{2} ; \\
& \rho\left(v_{i}, V_{i p}\right)=\left|v_{i}-\frac{a_{i p}+b_{i p}}{2}\right|-\frac{a_{i p}-b_{i p}}{2}
\end{aligned}
$$

The relevancy degree of the matter-element $P$ on the degree $j$ is

$$
K_{j}(P)=\sum_{i=1}^{n} W_{i} K_{j}\left(v_{i}\right)
$$

...where $W_{i}$ is the weight coefficient of the indicator.

\section{Determining the Assessment Degree}

If,

$$
K_{j \max }(P)=\max _{j=1}^{m}\left\{K_{j}(P)\right\}=K_{t o}(P)
$$

...then $\mathrm{P}$ belongs to degree $t_{0}$, assuming

$$
\begin{gathered}
\bar{K}_{j}(P)=\frac{K_{j}(P)-\min K_{j}(P)}{\max K_{j}(P)-\min _{j}(P)} \\
t^{*}=\frac{\sum_{i=1}^{m} j \overline{K_{j}}(P)}{\sum_{j=1}^{m} j \overline{K_{j}}(P)}
\end{gathered}
$$


...where $t^{*}$ is the rank variable characteristic value of $\mathrm{P}$. If $t_{0}=3, t^{*}=3.3$, which represents that the degree belongs between the 3 rd and 4 th degrees. The value of $t^{*}$ represents the extent of object trends to a certain degree.

\section{Antecedent-Effective Rainfall Attenuation Model}

In geological disaster-prone areas, rainfall frequently occurs and influences the process of the attenuation of one rain [54-56]. In order to simplify the problem, assume that each attenuation process of antecedent-effective rainfall is independent of each other. Each rainfall can be taken as an independent event to handle, and then the total antecedent effective precipitation can be obtained by the linear superposition of each antecedent effective precipitation [57-58]. See Eq. (22):

$$
A R=A R_{1}+A R_{2}+\cdots+A R_{n}=\sum_{i=1}^{n} A R_{i}
$$

...where $A R$ is the total antecedent effective rainfall, and $A R_{1}, A R_{2}$, and $A R_{n}$ are respectively the first, the second, and the $\mathrm{n}$-th effective precipitation before the final prediction. Precipitation attenuation regularity is substantially moisture attenuation regularity in geological disaster-prone areas.

Table 2. Geological disaster zonation extension methods of value evaluation index.

\begin{tabular}{|c|c|c|c|c|}
\hline Number & Indicators & Rank & Value Range & Standardization Value \\
\hline \multirow{4}{*}{$C 1$} & \multirow{4}{*}{$\begin{array}{c}\text { Forest } \\
\text { coverage }\end{array}$} & I & $>80 \%$ & $0 \sim 0.2$ \\
\hline & & II & $60 \% \sim 80 \%$ & $0.2 \sim 0.5$ \\
\hline & & III & $30 \% \sim 60 \%$ & $0.5 \sim 0.8$ \\
\hline & & IV & $0 \sim 30 \%$ & $0.8 \sim 1.0$ \\
\hline \multirow{4}{*}{$C 2$} & \multirow{4}{*}{$\begin{array}{l}\text { Annual } \\
\text { average } \\
\text { rainfall }\end{array}$} & I & $0 \sim 600$ & $0 \sim 0.3$ \\
\hline & & II & $600 \sim 800$ & $0.3 \mathrm{v} 0.65$ \\
\hline & & III & $800 \sim 1100$ & $0.65 \sim 0.8$ \\
\hline & & IV & $1100 \sim 1300$ & $0.8 \mathrm{v} 1.0$ \\
\hline \multirow{4}{*}{$C 3$} & \multirow{4}{*}{$\begin{array}{c}\text { Topography } \\
\text { and } \\
\text { gemorphogy }\end{array}$} & I & lava low mountain & $0 \sim 0.3$ \\
\hline & & II & lava high mountain & $0.3 \sim 0.5$ \\
\hline & & III & erosion of low mountain and hilly & $0.5 \sim 0.8$ \\
\hline & & IV & erosion of fluctuant middle mountain & $0.8 \sim 1.0$ \\
\hline \multirow{4}{*}{$C 4$} & \multirow{4}{*}{$\begin{array}{l}\text { Geological } \\
\text { structure }\end{array}$} & I & $>3$ & 1.0 \\
\hline & & II & 2 & 0.8 \\
\hline & & III & 1 & 0.4 \\
\hline & & IV & 0 & 0 \\
\hline \multirow{4}{*}{$C 5$} & \multirow{4}{*}{$\begin{array}{l}\text { Type of rock } \\
\text { and soil }\end{array}$} & $\mathrm{I}$ & hard carbonatite and intrusive rock & $0 \sim 0.3$ \\
\hline & & II & slightly hard carbonatite and hard sandy conglomerate & $0.3 \sim 0.6$ \\
\hline & & III & weak carbonatite and slightly hard sandy conglomerate & $0.6 \sim 0.8$ \\
\hline & & IV & weak sandy conglomerate and clay layer & $0.8 \sim 1.0$ \\
\hline \multirow{4}{*}{ C6 } & \multirow{4}{*}{$\begin{array}{c}\text { Amount of } \\
\text { geological } \\
\text { disaster point }\end{array}$} & I & $>3$ & 1.0 \\
\hline & & II & 2 & 0.8 \\
\hline & & III & 1 & 0.4 \\
\hline & & IV & 0 & 0 \\
\hline \multirow{4}{*}{$C 7$} & \multirow{4}{*}{$\begin{array}{c}\text { Human } \\
\text { engineering } \\
\text { activities }\end{array}$} & I & slight & $0 \sim 0.3$ \\
\hline & & II & slightly strong & $0.3 \sim 0.5$ \\
\hline & & III & strong & $0.5 \sim 0.8$ \\
\hline & & IV & extremely strong & $0.8 \sim 1.0$ \\
\hline
\end{tabular}




\section{Results and Discussion}

Based on the 1:100,000-scale geological hazards investigation and zoning map of Jilin Province, China, the study area was divided into 5,746 grid cells with each grid cell size of $5 \times 5 \mathrm{~km}$. According to the collected data, the factors of each cell were quantified [59]. As a matter-element for each cell, whose corresponding degree was determined by using the extenics model based on an optimal combination of empowerment theory.

In the application of the extenics model of geological disasters, according to the geological disaster investigation results and geological background conditions of Jilin, forest coverage, annual average rainfall, topography and gemorphogy, geological structure, type of rock and soil, the amount of disaster points, and human engineering activities were chosen as indicators of geological disaster assessment. Because each index value and the units used are different and some indicators are qualitative, which must be quantified, it is necessary to standardize them. In this paper, the range method was used to normalize the indicators to analyse. The results are shown in Table 2.

After the standardization of indicators, the classification criteria was defined as shown in Table 3.

\section{Weight Definition}

The weights of the indicators based on preference ratio method were:

$q_{j}=(0.0453,0.0960,0.1997,0.1668,0.1049,0.2905,0.0968)^{T}$

The weights of the indicators based on entropy method were:

$$
q_{j}=(0.123,0.207,0.103,0.048,0.132,0.266,0.121)^{T}
$$

The optimal combination of empowerment model was established and the optimal weights were obtained by solving the equation as follows:

$$
x_{1}^{\prime \prime}=0.7322, x_{1}^{\prime \prime}=0.2678 \text {, }
$$

$W=(0.0662,0.1257,0.1738,0.1350,0.1121,0.2839,0.1033)^{T}$

According to Eq. (3), the classical domains $R_{1}, R_{2}, R_{3}$, $R_{4}$, and $R_{p}$ were determined. Then take each grid cell as an assessment cell, quantify the indicators, and calculate the assessment results of each grid cell.

For example, the indicator values of a grid cell were:

$$
R_{1}=\left[\begin{array}{lll}
N_{1} & c_{1} & 0.4 \\
& c_{2} & 0.75 \\
& c_{3} & 0.70 \\
& c_{4} & 0.4 \\
& c_{5} & 0.25 \\
& c_{6} & 1.0 \\
& c_{7} & 0.3
\end{array}\right]
$$

By caculating the assessment index and judging the degree, $R_{1}$ belongs to degree IV, a highly vulnerable area. The other grid cells were judging their degree by the same method. Finally, the geological disaster assessment map of Jilin Province was drawn (Fig. 2).

According to the susceptibility of geological disasters in Jilin extension evaluation, follow the "same in the region and different interregional" principle, take the cells with the same degree as a entirety area, and form the geological disasters susceptibility zonation map of Jilin Province (Fig. 3). Through field geological disaster survey the geological disasters were found developed in Tonghua, Ji'an, Linjiang, and Antu areas, and there were a large number of geological disasters in the flood season each year. These areas were located in the highly vulnerable geological disaster areas. The Western Plains, which has few geological disasters, is located in the low or very low vulnerable areas. The zonation results coincide with the field investigation, which shows that the zonation is scientific and reaso-

\begin{tabular}{|c|c|c|c|c|c|}
\hline \multirow{2}{*}{ Number } & \multirow{2}{*}{ Indicators } & \multicolumn{4}{|c|}{ Geological disaster zonation } \\
\hline & & High (IV) & Moderate (III) & Low (II) & Very low (I) \\
\hline$C 1$ & forest coverage & $0.8 \sim 1.0$ & $0.4 \sim 0.8$ & $0.2 \sim 0.4$ & $0 \sim 0.2$ \\
\hline$C 2$ & annual average rainfall & $0.8 \sim 1.0$ & $0.6 \sim 0.8$ & $0.2 \sim 0.6$ & $0 \sim 0.2$ \\
\hline$C 3$ & topography and gemorphogy & $0.8 \sim 1.0$ & $0.5 \sim 0.8$ & $0.3 \sim 0.5$ & $0 \sim 0.3$ \\
\hline$C 4$ & geologic structure & $0.8 \sim 1.0$ & $0.6 \sim 0.8$ & $0.3 \sim 0.6$ & $0 \sim 0.3$ \\
\hline$C 5$ & type of rock and soil & $0.7 \sim 1.0$ & $0.5 \sim 0.7$ & $0.3 \sim 0.5$ & $0 \sim 0.3$ \\
\hline C6 & amount of geological hazad point & $0.7 \sim 1.0$ & $0.4 \sim 0.7$ & $0.2 \sim 0.4$ & $0 \sim 0.2$ \\
\hline$C 7$ & human engineering activitics & $0.7 \sim 1.0$ & $0.4 \sim 0.7$ & $0.2 \sim 0.4$ & $0 \sim 0.2$ \\
\hline
\end{tabular}
nable.

Table 3. Classification criteria for indicators of geological disaster zonation. 


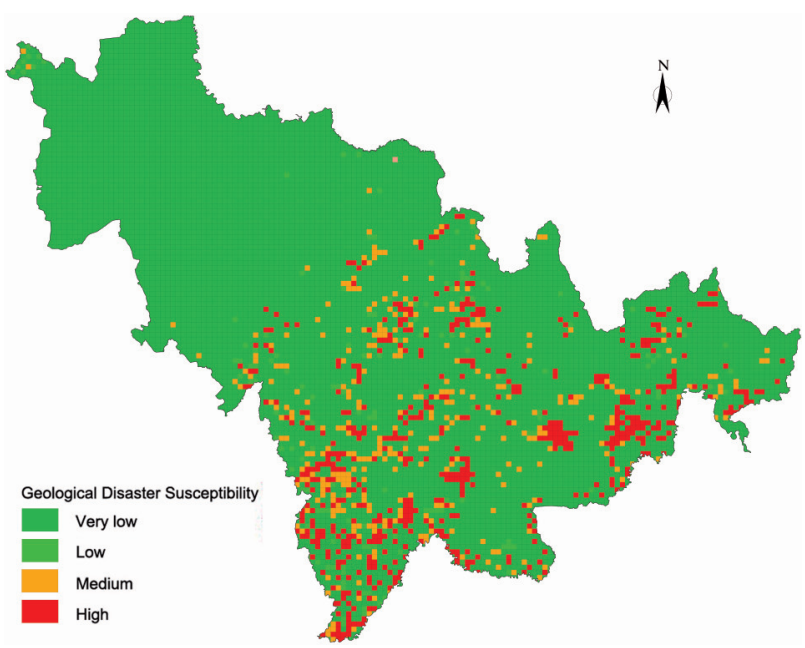

Fig. 2. Geological disasters susceptibility maps of Jilin Province, China, obtained from extension model.

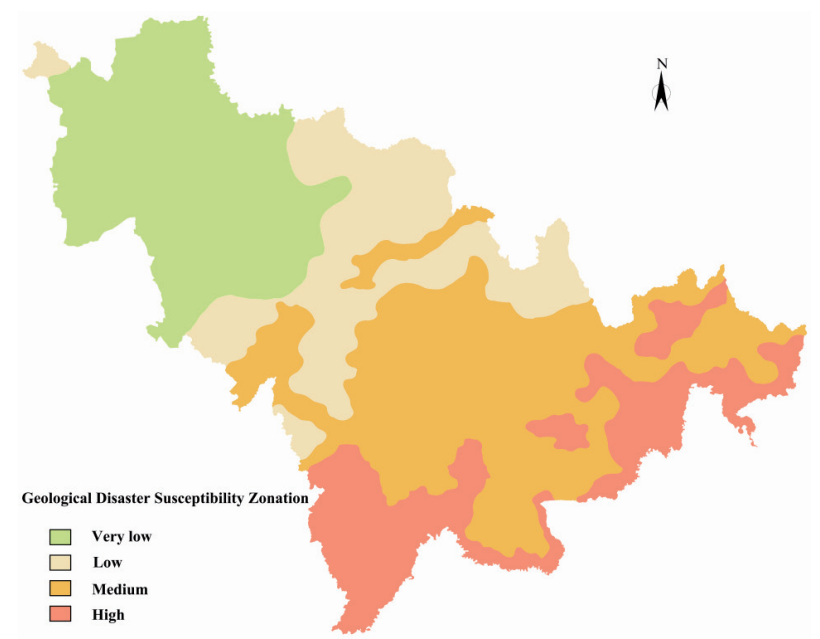

Fig. 3. Geological disaster susceptibility zonation map of Jilin Province, China.

\section{High Geological Disaster Susceptibility Area}

The area is mainly found in the Changbai Mountains, where there are intensive geological structures, complex rock and soil types, intensive human activity, and high annual average rainfall. The area is $34,059 \mathrm{~km}^{2}$, which accounts for $18.17 \%$ of total area. The geological disaster point total is 1,969 , accounting for $51.79 \%$ of the total geological disasters, which contain 1,095 collapses, 149 landslides, 653 debris flows, and 72 cracking and ground subsidence. The average density of geological hazards is $5.78 / 100 \mathrm{~km}^{2}$

\section{Medium Geological Disaster Susceptibility Area}

This area mainly is distributed in eastern Jilin with its hilly and low mountain area, where the rock and soil types in the region offer more or higher concentrations of geological structures. The area is $64,976 \mathrm{~km}^{2}$, accounting for $34.67 \%$ of total area. The geological disaster point total is 1,183 , accounting for $31.11 \%$ of the total geological disasters, which contain 551 collapses, 63 landslide, 478 debris flows, and 91 cracking and ground subsidence episodes. The average density of geological hazards is $1.82 / 100 \mathrm{~km}^{2}$.

\section{Low Geological Disaster Susceptibility Area}

This area is mainly distributed in the area where the rock and soil type is less and the density of geological structure is low. The area is $37,391 \mathrm{~km}^{2}$, accounting for $19.95 \%$ of total area. The geological disaster points total 374 , accounting for $9.83 \%$ of the total geological disasters, which contain 259 collapses, three landslides, 109 debris flows, and three cracking and ground subsidence episodes. The average density of geological hazards is $1 / 100 \mathrm{~km}^{2}$. The region is characterized by less developed geological structures, good forest vegetation, and relatively small population density, which combine to make more geological disasters unlikely.

\section{Very Low Geological Disaster Susceptibility Area}

This area mainly is distributed in the Western Plain area, where the rock and soil types are less. The area is $50,974 \mathrm{~km}^{2}$, accounting for $27.2 \%$ of total area. Formation lithology mainly contains the loess loam, sandy soil, sand, and mudstone, etc. The geological disaster points total three, accounting for $0.008 \%$ of the total geological disasters, which include two collapses and one debris flow. The average density of geological hazards is $0.0059 / 100 \mathrm{~km}^{2}$. The region is characterized by undeveloped geological structures and good geological environment in which more geological disasters are unlikely.

\section{Building a Forecast and Early Warning Model Based on Antecedent-Effective Rainfall}

Improving the forecast and early warning levels of geological disasters plays an important role in establishing a geological disaster early warning and forecast model. When the forecasting accuracy is above $50 \%$, the local government's disaster prevention and reduction will be effectively guided and the mass monitoring and mass preventing work will be more targeted. The geological disaster early warning and forecast model of Jilin was established on the basis of geological disaster early warning and forecast zonation, and according to the statistical analysis of geological disaster forewarning and forecast results and the actual occurring frequency. Because the forecast precipitation occurring in the warning area may play a role in triggering geological disasters, according to the antecedent precipitation data, the Jilin 
Table 4. Classfication criteria of $\mathrm{P}$ value.

\begin{tabular}{|c|c|c|c|c|c|}
\hline $\begin{array}{c}\text { Warning } \\
\text { level }\end{array}$ & V & IV & III & II & I \\
\hline $\begin{array}{c}\text { Creteria } \\
\text { value }\end{array}$ & $\mathrm{P} \geq 150$ & $150>\mathrm{P} \geq 110$ & $110>\mathrm{P} \geq 75$ & $75>\mathrm{P} \geq 50$ & $50>\mathrm{P}$ \\
\hline
\end{tabular}

geological disaster forecast and early-warning model has been established as follows:

$$
P=\mathrm{V} \cdot R
$$

...where $P$ is the comprehensive index of early warning and forcast; $v$ is the vulnerable index, the high vulnerable area, $v=1.5$, in moderate vulnerale area, $v=1.25$ and in low vulnerable area, and $v=1.0 . R$ is the antecedent effective precipitation amount.

When the forecast and early warning index value $P$ range from different values, the government will issue the relevant warning level. The classfication criteria of $\mathrm{P}$ value is shown in Table 4.

\section{Application of the Model}

The precipitation of 2011 in Jilin is basically as same as the normal level. In the flood season of 2011, using the model to forecast and warn the geological disaster in Jilin, the III degree early warning information was issued nine times, of which seven were real disasters. The forecast success rate was $78 \%$.

\section{Conclusions}

Several factors that forest coverage, annual average rainfall, topography and gemorphogy, geological structure, type of rock and soil, the amount of disaster points, and human engineering activities have a significant impact on geological disaster development. In this paper, according to these factors, considering the strength, distribution, and development trends of geological disasters, the geological disaster susceptibility zonation was drawn using an optimal combination of empowerment model and extenics theory. And, according to the results, combined with the actual rainfall in previous years at the time of each geological disaster, the geological disaster early warning and forecast model of Jilin was established. After that, the model was applied in Jilin to forecast and warn the geological disaster. The conclusions are as follows:

1) Extension is the rule and method to solve the incompatibility problem qualitatively and quantitatively by formalized tools. This method realized the uniformization of multiple indicators and achieved the object of reasonable zonation. Determining weight coefficients in extension assessment plays an important role. Their reasonaility directly affects the accuracy of the evaluation results. Establishing an optimal combination of empowerment theory overcame the over-subjective problem by preference ratio method and the over-objective problem by the entropy method. It is an optimal combination of subjective and objective weighting method, which is an innovative and significant exploration.

2) According to the extenics model based on optimal combination of empowerment theory, geological disaster susceptibility zones in Jilin province are divided into four areas, which is of great significance to guide disaster prevention and disaster reduction work in the province.

3) According to the division of early warning results, combined with the actual preciptation during the geological disasters in previous years, the geological disasters forecasting and warning model of Jilin was built. Through practical application the results show that this model has a relatively high accuracy of forecast and early warning. The results have guiding significance for the prevention and control of geological disasters in the province.

\section{Acknowledgements}

This study was supported by the National Key Technology R\&D Program of China under grant No. 2013BAK05B01, the Science and Technology Development Plan projects of Jilin Province under grant Nos. 20150204024SF and 20170204035SF, and the National Natural Science Foundation of China under grant No. 41371495. The authors are grateful to the anonymous reviewers for their insightful and helpful comments that helped improve the manuscript.

\section{References}

1. CHEN T., NIU R., JIA X. A comparison of information value and logistic regression models in landslide susceptibility mapping by using GIS. Environmental Earth Sciences. $\mathbf{7 5}$ (10), 867, 2016.

2. DAI F. C., LEE C. F., NGAI Y. Y. Landslide risk assessment and management: an overview. Engineering Geology. 64 (1), 65, 2002.

3. QIAN X., CHEN J., XIANG L., ZHANG W., NIU C. A novel hybrid KPCA and SVM with PSO model for identifying debris flow hazard degree: a case study in Southwest China. Environmental Earth Sciences. 75 (991), 2016.

4. KOMENDANTOVA N., MRZYGLOCKI R., MIGNAN A., KHAZAI B., WENZEL F., PATT A., FLEMING K. Multi-hazard and multi-risk decision-support tools as a part of participatory risk governance: Feedback from civil protection stakeholders. International Journal of Disaster Risk Reduction. 8, 50, 2014.

5. HUANG C.C, SHECHIEH Y. Experimental investigation of rainfall criteria for shallow slope failures. Geomorphology. 120 (3), 326, 2010.

6. GAO W.Y., MING L.I., JI-WEN D.U. New Thought of Meteorological Forecasting and Warning Models of Geological Disasters in Loess Plateau of North Shaanxi. Meteorological and Environmental Research. 1 (8), 12, 2010. 
7. YOUSSEF A.M., MAERZ N.H. Overview of some geological hazards in the Saudi Arabia. Environmental Earth Sciences. 70 (7), 3115, 2013.

8. CHENG Y., HUO A. Geo-hazard Risk Evaluation in Huangling County Shaanxi Province. Energy Procedia. 13, 10304-10309, 2011.

9. YOSHIMATSU H., ABE S. A review of landslide hazards in Japan and assessment of their susceptibility using an analytical hierarchic process (AHP) method. Landslides. 3 (2), 149, 2006

10. CHENG Y., HUO A., ZHANG J., LU Y. Early warning of meteorological geohazard in the Loess Plateau: a study in Huangling County of Shaanxi Province in China. Environmental Earth Sciences. 73 (3), 1057, 2015.

11. PENG L., NIU R., HUANG B., WU X., ZHAO Y., YE R. Landslide susceptibility mapping based on rough set theory and support vector machines: A case of the Three Gorges area, China. Geomorphology. 204 (1), 287, 2014.

12. STEGER S., BRENNING A., BELL R., GLADE T. The propagation of inventory-based positional errors into statistical landslide susceptibility models. Natural Hazards and Earth System Sciences. 16 (12), 2729, 2016.

13. CHEN L., VAN WESTEN C.J., HUSSIN H., CIUREAN R.L., TURKINGTON T., CHAVARRO-RINCON D., SHRESTHA D. P. Integrating expert opinion with modelling for quantitative multi-hazard risk assessment in the Eastern Italian Alps. Geomorphology. 273, 150, 2016.

14. XU D., LIU. The Relationship Between the Landslide and Debris Flows and the Precipitation in Yunnan Province Under Conditions of Different Geology and Geomorphology. Meteorological Monthly. 33 (9), 33, 2007.

15. FALL M., AZZAM R., NOUBACTEP C. A multi-method approach to study the stability of natural slopes and landslide susceptibility mapping. Engineering Geology. 82 (4), 241, 2006.

16. ANBALAGAN R., KUMAR R, LAKSHMANAN K, PARIDA S, NEETHU S. Landslide hazard zonation mapping using frequency ratio and fuzzy logic approach, a case study of Lachung Valley, Sikkim. Geoenvironmental Disasters. 2, 6, 2015.

17. CHANG T. Risk degree of debris flow applying neural networks. Natural Hazards. 42 (1), 209, 2007.

18. YANG Z.J., QIAO J.P., HUANG D., TIAN H.L., JIANG Y.J., SHI L. A Multi-Scaled Early Warning Method for Rainfall-Induced Mountain Hazards. Springer International Publishing, 619, 2014.

19. OZDEMIR A., ALTURAL T. A comparative study of frequency ratio, weights of evidence and logistic regression methods for landslide susceptibility mapping: Sultan Mountains, SW Turkey. Journal of Asian Earth Sciences. 64, 180, 2013.

20. PAPADOPOULOU-VRYNIOTI K., BATHRELLOS G.D., SKILODIMOU H.D., KAVIRIS G., MAKROPOULOS K. Karst collapse susceptibility mapping considering peak ground acceleration in a rapidly growing urban area. Engineering Geology. 158 (8), 77, 2013.

21. POURGHASEMI H.R., PRADHAN B., GOKCEOGLU C., MOHAMMADI M., MORADI H.R. Application of weights-of-evidence and certainty factor models and their comparison in landslide susceptibility mapping at Haraz watershed, Iran. Arabian Journal of Geosciences. 6 (7), 2351, 2013

22. MORADI M., BAZYAR M.H., MOHAMMADI Z. GISbased landslide susceptibility mapping by AHP method, a case study, Dena City, Iran. Journal of Basic and Applied Scientific Research. 2 (7), 6715, 2012.
23. INTARAWICHIAN N., DASANANDA S. Frequency ratio model based landslide susceptibility mapping in lower Mae Chaem watershed, Northern Thailand. Environmental Earth Sciences. 64 (8), 2271, 2011.

24. PRADHAN B., MANSOR S., PIRASTEH S., BUCHROITHNER M. F. Landslide hazard and risk analyses at a landslide prone catchment area using statistical based geospatial model. International Journal of Remote Sensing. 32 (14), 4075, 2011.

25. CANOVAS J.A.B., STOFFEL M., CORONAC., SCHRAML K., GOBIET A., TANI S., SINABELL F., FUCHS S., KAITNA R. Debris-flow risk analysis in a managed torrent based on a stochastic life-cycle performance. Science of the Total Environment. 557, 142-153, 2016.

26. LI Z., SHI W., LU P., YAN L., WANG Q., MIAO Z. Landslide mapping from aerial photographs using change detection-based Markov random field. Remote Sensing of Environment. 187, 76, 2016.

27. VON RUETTE J., LEHMANN P., OR D. Linking rainfallinduced landslides with predictions of debris flow runout distances. Landslides. 13 (5), 1097, 2016.

28. FREY H., HUGGEL C., BUHLER Y., BUIS D., DULCE BURGA M., CHOQUEVILCA W., FERNANDEZ F., HERNANDEZ J. G., GIRALDEZ C., LOARTE E., MASIAS P., PORTOCARRERO C., VICUNA L., WALSER M. A robust debris-flow and GLOF risk management strategy for a data-scarce catchment in Santa Teresa, Peru. Landslides. 13 (6), 1493, 2016

29. AHMAD I., FAWAD M., AKBAR M., ABBAS A. Regional Frequency Analysis of Annual Peak Flows in Pakistan Using Linear Combination of Order Statistics. Polish Journal of Environmental Studies. 25 (6), 1, 2016.

30. KAYASTHA P., DHITAL M.R., SMEDT F.D. Evaluation and comparison of GIS based landslide susceptibility mapping procedures in Kulekhani watershed, Nepal. Journal of the Geological Society of India. 81 (2), 219, 2013.

31. PRADHAN B. A comparative study on the predictive ability of the decision tree, support vector machine and neurofuzzy models in landslide susceptibility mapping using GIS. Computers \& Geosciences. 51 (2), 350, 2013.

32. DEVKOTA K.C., REGMI A.D., POURGHASEMI H.R., YOSHIDA K., PRADHAN B., RYU I.C., DHITAL M.R., ALTHUWAYNEE O.F. Landslide susceptibility mapping using certainty factor, index of entropy and logistic regression models in GIS and their comparison at MuglingNarayanghat road section in Nepal Himalaya. Natural Hazards. 65 (1), 135, 2013.

33. AKGUN A., KiNCAL C., PRADHAN B. Application of remote sensing data and GIS for landslide risk assessment as an environmental threat to Izmir city (west Turkey). Environmental Monitoring \& Assessment. 184 (9), 5453, 2012.

34. PENG S.H., SHIEH M.J., FAN S.Y. Potential Hazard Map for Disaster Prevention Using GIS-Based Linear Combination Approach and Analytic Hierarchy Method. Journal of Geographic Information System. 4 (5), 403, 2012.

35. ROZOS D., BATHRELLOS G.D., SKILLODIMOU H.D. Comparison of the implementation of rock engineering system and analytic hierarchy process methods, upon landslide susceptibility mapping, using GIS: a case study from the Eastern Achaia County of Peloponnesus, Greece. Environmental Earth Sciences. 63 (1), 49, 2011.

36. AYALEW L., YAMAGISHI H. The application of GIS-based logistic regression for landslide susceptibility mapping in the Kakuda-Yahiko Mountains, Central Japan. Geomorphology. 65 (1-2), 15, 2005. 
37. SEZER E.A., NEFESLIOGLU H.A., OSNA T. An expertbased landslide susceptibility mapping (LSM) module developed for Netcad Architect Software. Computers \& Geosciences. 98, 26, 2017.

38. WANG W., ZHANG H., ZHENG L., ZHANG Y., WU Y., LIU S. A new approach for modeling landslide movement over 3D topography using 3D discontinuous deformation analysis. Computers and Geotechnics. 81, 87, 2017.

39. LEE S. Application of logistic regression model and its validation for landslide susceptibility mapping using GIS and remote sensing data. International Journal of Remote Sensing. 26 (7), 1477, 2005.

40. LIU J.G., MASON P.J., CLERICI N., CHEN S., DAVIS A., MIAO F., DENG H., LIANG L. Landslide hazard assessment in the Three Gorges area of the Yangtze river using ASTER imagery: Zigui-Badong. Geomorphology. 61 (1-2), 171, 2004.

41. PETSCHKO H., BELL R., GLADE T. Effectiveness of visually analyzing LiDAR DTM derivatives for earth and debris slide inventory mapping for statistical susceptibility modeling. Landslides. 13 (5), 857, 2016.

42. NOURANI V., PRADHAN B., GHAFFARI H., SHARIFI S. S. Landslide susceptibility mapping at Zonouz Plain, Iran using genetic programming and comparison with frequency ratio, logistic regression, and artificial neural network models. Natural Hazards. 71 (1), 523, 2014.

43. AUTHOR S.L.C., CHOI J., MIN K. Probabilistic landslide hazard mapping using GIS and remote sensing data at Boun, Korea. International Journal of Remote Sensing. 25 (11), 2037, 2004.

44. MENG F.Q., GUANG-JIE L.I., WANG Q.B., QIN S.W., ZHAO H.Q., XIN J. Research on early warning of debris flow based on efficacy coefficient method. Rock \& Soil Mechanics. 33 (3), 835, 2012.

45. BAY S.D., PAZZANI M.J. Detecting Group Differences: Mining Contrast Sets. Data Mining and Knowledge Discovery. 5 (3), 213, 2001.

46. WANG Y.C., SHANG Y.Q., SUN H.Y., YAN X.S. Study of prediction of rockburst intensity based on efficacy coefficient method. Yantu Lixue/rock \& Soil Mechanics. 31 (2), 529, 2010.

47. WANG M., ZHANG F., LIU Z. Evaluation method of the multi-attribute scheme based on entropy weight of fuzzy information. Systems Engineering \& Electronics. 28 (10), 1523, 2006.

48. WEI Q., YAN H. A method of transferring polyhedron between the intersection-form and the sum-form. Computers \& Mathematics with Applications. 41 (10), 1327, 2001.

49. CAI W. Introduction of Extenics. Systems EngineeringTheory \& Practice. 18 (1), 76, 1998.

50. YANG C., CAI W., TU X. Research, application and development on extenics. Journal of Systems Science and Mathematical Sciences. 36 (9), 1507, 2016.

51. YE J. Application of extension theory in misfire fault diagnosis of gasoline engines. Expert Systems with Applications. 36 (2), 1217, 2009.

52. WANG M.H., TSENG Y.F., CHEN H.C., CHAO K.H. A novel clustering algorithm based on the extension theory and genetic algorithm. Expert Systems with Applications. 36 (4), 8269, 2009

53. ZHENG G., JING Y., HUANG H., ZHANG X., GAO Y. Application of Life Cycle Assessment (LCA) and extenics theory for building energy conservation assessment. Energy. 34 (11), 1870, 2009.

54. XU W., YU W., ZHANG G. Prediction method of debris flow by logistic model with two types of rainfall: a case study in the Sichuan, China. Natural Hazards. 62 (2), 733, 2012.

55. MILLER S., BREWER T., HARRIS N. Rainfall thresholding and susceptibility assessment of rainfall-induced landslides: application to landslide management in St Thomas, Jamaica. B Eng Geol Environ. 68 (4), 539, 2009.

56. BUI D.T., TUAN T.A., HOANG N.D., THANH N.Q., NGUYEN D.B., LIEM N.V., PRADHAN B. Spatial prediction of rainfall-induced landslides for the Lao Cai area (Vietnam) using a hybrid intelligent approach of least squares support vector machines inference model and artificial bee colony optimization. Landslides., 1, 2016.

57. WEI F., HU K., CHEN J. Determination of Effective Antecedent Rainfall for Debris Flow Forecast. Journal of Mountain Research. 4, 11, 2005.

58. LOURAKIS M.I. A brief description of the LevenbergMarquardt algorithm implemented by levmar. Foundation of Research and Technology. 4, 1, 2005.

59. DAI F.C., LEE C.F. Landslide characteristics and slope instability modeling using GIS, Lantau Island, Hong Kong. Geomorphology. 42 (3-4), 213, 2002. 